\title{
A GOOD TIME
}

\author{
A real body blow.
}

\section{BY SHELLY LI}

$\mathrm{W}$ henever he got drunk, my old man would tell me: "If you're looking to get married and have kids and a white picket fence, get a girlfriend. If you got a girlfriend when all you're looking for is sex ... you're overpaying." Sometimes I wonder if he was the same guy before Ma left him.

Driving down the street, I can feel the car engine humming in my fingertips as I grip the wheel. During the day, I follow the rules and let the car drive itself. It speeds up the traffic, I know. But at night, I love sitting in the driver's seat, tilting my wrist left and right, and watching the car heed my will. This baby is one of the only things I've got to show for five years and counting in investment banking.

Stoplight colours blur together at the speed that I'm going. Everything in my peripherals has long folded into a grey vortex.

Thirty miles later, I find myself downtown, and I ease onto the brake. Cops don't usually hang around here, but I slow down anyway to enjoy the moment.

The lights, the scarce number that there are on this street, solidify to a standstill. All along the walls, young women line up like prisoners waiting to be decimated. They stand casually, though, a nonchalant shrug in their shoulders, a carefree glint in their eyes. You won't find a girl more beautiful than one on this street. You also won't find a real one - real girl, I mean.

Prostitution only became legal after the robotics companies took over the business. It was just more tax money to collect, so the mayor didn't seem to mind. Who knows? Maybe the potholes in my neighbourhood were finally fixed last year at the expense of some socially stunted invalid who scheduled daily appointments of sexual therapy?

I pull up by the kerb and roll down my window. Immediately, a pretty little thing steps forward and fills the frame. "Hey there," she says, the fine tips of her dark hair brushing my left arm. She looks over the inside of my car first, checking to see how much I'll be capable of paying. Quality and price are adjusted per client. "Whatcha lookin' for, handsome?"

I open my mouth to tell her that I'm looking for an escape, but all that comes out are

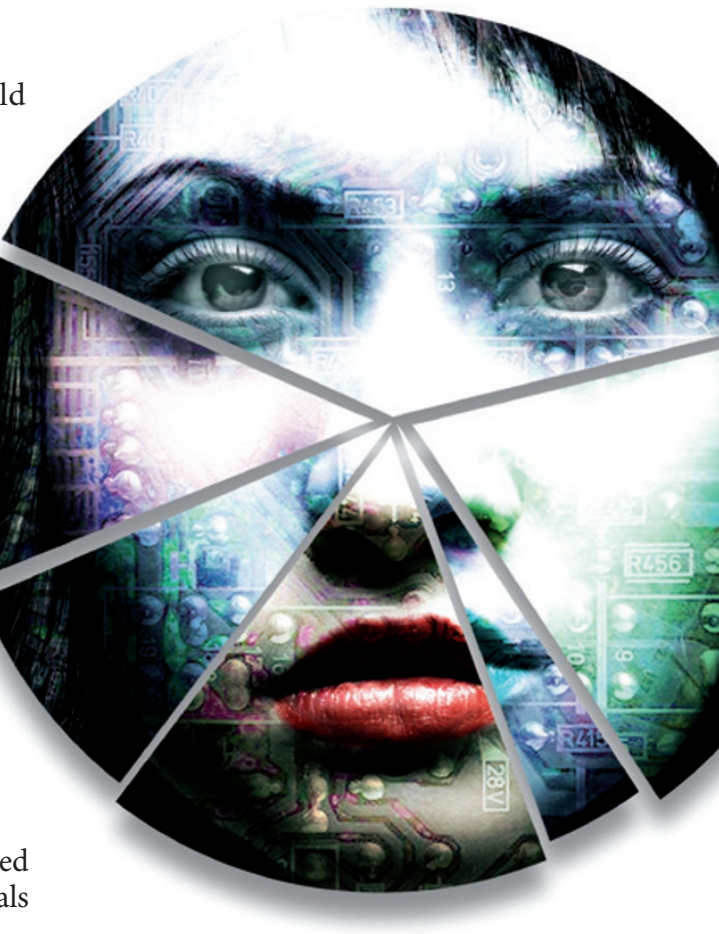

the cliché words I'm used to saying. "A good time."

The woman smiles before slowly raising her head to make eye contact. Her blue-grey eyes are arresting, and looking at them is like viewing the ocean from space, watching drifting silver clouds blanket a massive body of glittering blue. The company, whichever one she belongs to, must have spent extra time producing this model.

Finally she says: "Sorry, not selling that today." And with that, she backs away from my car and turns to leave.

"Hey, wait," I call out. For a moment my mind freezes, and I have no idea what to say as she turns around to face me again. Did that just happen? "You're not allowed to turn me down."

The woman blinks. "For the next month, I will be. Companies are ordered to regenerate their models."

Frustration courses through my blood, pent-up anger rising from God knows where.

"Regenerate what? This is not right. I want to speak with your ... manager - I mean supervisor - I mean, pimp. Whatever you call him."

At this the woman

$\rightarrow$ NATURE.COM

Follow Futures on Facebook at: go.nature.com/mtoodm lets out a warm and husky laugh. She walks forward and hands me a business card. "Call the number on the card," she says. "Or you can send a message to customer service."

I stare blankly at the card between my fingers, shocked and confused and maybe even a little hurt. Sitting in my 760 BMW, window rolled down, a piercing autumn wind seeping through my sweater, Pa's voice pops into my head. I can just imagine him muttering quietly to me, the scent of Myer's Rum lacquered to his breath: "Son, you know you've reached a new low when a whore tells you no." After a long pause, the woman starts to walk away again.

My stomach does a flip, and I call after her. "You selling anything at all?" The desperation in my voice is glaring, one that I cannot seem to control or understand. If I want, I can call up any old college girlfriend and set up a latenight rendezvous. This is about more than sex. If I'm honest, it's always about more than sex.

The woman sighs, her breath curling up as a silver wisp in the night air. She puts her hands on her hips and turns around, looking annoyed now. It suddenly occurs to me that I do not know whether she can feel or not. Robots can surely reason, so why shouldn't they be able to feel? I wonder why I never bothered to wonder this before.

"What do you do for a living?" she asks me.

I frown at the question. "I'm an investment banker. Why?"

"Oh, fantastic. This'll be easy to explain." She takes a few steps closer to my car, but stays a casual five feet away. "Supply and demand. In order to keep the demand high, the government must limit supply. You and I, we're all just part of the business, sugar."

This time, when she walks away, I make no attempt to stop her. Soon she disappears around a corner, becoming a shadow against an adjacent wall, and then a phantom.

I roll my window up and lean back against my car seat. A minute or so passes, and I begin to chuckle at my foolishness. Hitting the side of my steering wheel, I drive off. The lights all blur together again.

The microeconomics of prostitution. Now there's a class I missed in graduate school.

Shelly Li has published more than 20 short stories. Her first novel, The Royal Hunter, is forthcoming from Philomel Books. For more information, visit: $w$ ww.shelly-li.com. 